\title{
STUDIES ON THE OA-6129 GROUP OF ANTIBIOTICS, NEW CARBAPENEM COMPOUNDS \\ I. TAXONOMY, ISOLATION AND PHYSICAL PROPERTIES
}

\author{
Mitsuyasu Okabe, Shoji Azuma, Ikuo Kojima, Kageaki Kouno, \\ RoKURO OKAMOTO, YASUO FUKAGAWA and TOMOYUKI IsHIKURA \\ Sanraku-Ocean Co., Ltd., Central Research Laboratories, \\ 9-1 Johnan 4-chome, Fujisawa 251, Japan
}

(Received for publication June 29, 1982)

\begin{abstract}
Streptomyces sp. OA-6129, a soil actinomycete, was found to produce a new group of carbapenem antibiotics named OA-6129A, OA-6129B 1, OA-6129B $B_{2}$ and OA-6129C. The taxonomy of the producer and the isolation and physicochemical properties of these new carbapenem compounds are described.
\end{abstract}

In previous papers, we have described the production of the PS group of antibiotics (PS- $5^{1)}$, PS- $6^{2)}$, PS-72) and PS- ${ }^{3)}$ ) by streptomycetes. In the continued screening for new $\beta$-lactam antibiotics, we have discovered new carbapenem antibiotics in the fermentation broth of a soil actinomycete.

For convenience of explanation, the chemical structures of these new compounds are shown in Fig. 1. Chemical structures of the OA-6129 group of carbapenems.

Fig. 1. The detailed chemical studies on the OA6129 group of carbapenem compounds will be published elsewhere ${ }^{4)}$. It is apparent from Fig. 1 that the OA-6129 group of antibiotics differ in the C-3 pantetheinyl side chain not only from the PS group of antibiotics but also from the other hitherto-known carbapenem compounds ${ }^{5 \sim 10)}$.

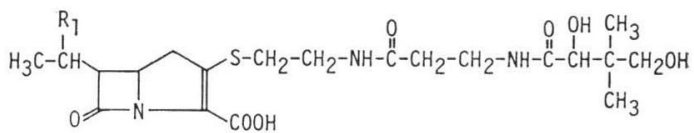

OA-6129A $\quad \mathrm{R}_{1}=-\mathrm{H}$

$\mathrm{OA}-6129 \mathrm{~B}_{1} \quad \mathrm{R}_{1}=-\mathrm{OH}$

$\mathrm{OA}-6129 \mathrm{~B}_{2} \quad \mathrm{R}_{1}=-\mathrm{OH}$

$\mathrm{OA}-6129 \mathrm{C} \quad \mathrm{R}_{1}=-\mathrm{OSO}_{3} \mathrm{H}$

This paper describes the taxonomy of the producing organism and the isolation and physicochemical properties of OA-6129A, OA-6129B , OA-6129B $_{2}$ and OA-6129C.

\section{Materials and Methods}

\section{Chemicals}

PS-5 (sodium salt) was prepared in our laboratories as described in a previous report ${ }^{1}$.

Disk-agar Diffusion Assay

Overnight culture of Comamonas terrigena B-996 on a nutrient agar slant was suspended in nutrient broth to give a seed cell suspension which had an optical density of 0.040 at $610 \mathrm{~nm}^{1)}$. One percent of the seed cell suspension was inoculated in molten agar medium consisting of $0.8 \%$ Kyokuto Nutrient Broth Powder (Kyokuto Seiyaku Kogyo Co., Ltd., Japan) and 1.0\% Bacto-agar (Difco Laboratories, U.S.A.). Seven milliliters of the inoculated molten agar medium was poured into a 9-cm Petri dish and allowed to solidify to provide a Comamonas-disk assay plate.

\section{Bioautography}

Instead of a 9-cm Petri dish, a $32 \times 24 \mathrm{~cm}$ tray was filled with $100 \mathrm{ml}$ of the inoculated molten agar medium. A sheet of chromatographic paper on which antimicrobial compounds had been developed 
in a suitable solvent system was air-dried for removal of the solvent and was then kept for 15 minutes in contact with the surface of the agar medium. After the chromatogram was removed, the agar assay tray was incubated at $30^{\circ} \mathrm{C}$ for 20 hours.

Thin-layer Chromatography

A new thin-layer chromatographic method was devised for qualitative and semi-quantitative analysis of the OA-6129 group of carbapenem compounds. Assay samples were spotted on a precoated silica gel thin-layer plate (silica gel $60 \mathrm{~F}_{254}$; E. Merck, Darmstadt) and developed in an appropriate solvent system. The OA-6129 group of carbapenem compounds were visualized with the Ehrlich reagent. This thin-layer chromatographic method will be detailed in a separate report ${ }^{11)}$.

pH Stability Test

Monopotassium phosphate $(0.05 \mathrm{M})$ solution was adjusted to the indicated pH's by adding $2 \%$ sodium hydroxide or $10 \%$ hydrochloric acid, and distributed in $3 \mathrm{ml}$ volumes into test tubes. $0.05 \mathrm{ml}$ each of OA-6129A (sodium salt) or PS-5 (sodium salt) solution $(2 \mathrm{mg} / \mathrm{ml}$ ) was added to the buffer solutions and incubated at $28^{\circ} \mathrm{C}$. The concentration of the unchanged antibiotic was measured at $300 \mathrm{~nm}$ by spectrometry.

\section{Results and Discussion}

\section{Taxonomical Study of Strain OA-6129}

By a modification of the previously-described screening system for $\beta$-lactam compounds ${ }^{1)}$ in which the thin-layer chromatographic analysis was included for selective detection of carbapenem compounds in fermentation broths, a soil microorganism which was found to produce seemingly new carbapenem antibiotics was isolated from a soil sample collected near the Sumiyoshi Shrine in Fukuoka-shi, Japan. The soil isolate was taxonomically studied by the methods of ShirLing and GotTLIEB ${ }^{12 \sim 18)}$; PrIdHAm and TRESNER ${ }^{17)}$; WAKSMAN ${ }^{18)}$.

\section{Morphological Characteristics}

On slide glass cultivation, straight or flexuous aerial mycelia without verticillate branchings grow from well-branched substrate mycelia. A mature spore chain usually consists of more than ten elliptical or cylindrical spores. Spores are non-flagellated; $0.6 \sim 1.0 \times 0.7 \sim 2.5$ microns in size; and have smooth surfaces. No sporangium is observed.

Cultural Characteristics

Table 1 summarizes the cultural characteristics of strain OA-6129. Unless specifically stated, the microorganism was cultured at a temperature of $28 \sim 30^{\circ} \mathrm{C}$. According to the method of TRESNER and BACKUS ${ }^{20)}$, the color symbols in parentheses refer to the Color Harmony Manual of Container Corporation of America ${ }^{19)}$.

\section{Physiological Characteristics}

Table 2 shows the physiological properties of strain OA-6129. Gelatin liquefaction, starch hydrolysis and milk peptonization are positive, whereas milk coagulation and melanoid formation are negative.

The carbohydrate utilization pattern of strain OA-6129 is presented in Table 3.

Based on the above-described taxonomical findings, strain OA-6129 was concluded to belong to Streptomyces. A culture of Streptomyces sp. OA-6129 has been deposited at the Fermentation Research Institute, Agency of Industrial Science and Technology, Japan with the deposit number of FERM BP-11. 
Table 1. Cultural characteristics of strain OA-6129.

\begin{tabular}{|c|c|c|c|c|c|}
\hline Nutrient agar & $\begin{array}{l}\mathrm{G}^{*}: \\
\mathrm{AM}: \\
\mathrm{SM}: \\
\mathrm{SP}:\end{array}$ & $\begin{array}{l}\text { abundant } \\
\text { light grayish reddish } \\
\text { brown [5fe] } \\
\text { pale yellow [2db] or light } \\
\text { yellow [2fb] light olive } \\
\text { brown [2ge] } \\
\text { none }\end{array}$ & $\begin{array}{l}\text { Sucrose - nitrate } \\
\text { agar }\end{array}$ & $\begin{array}{l}\text { G: } \\
\text { AM: } \\
\text { SM: } \\
\text { SP: }\end{array}$ & $\begin{array}{l}\text { moderate } \\
\text { yellowish gray }[2 \mathrm{dc}] \sim \\
\text { grayish pink [5dc] } \\
\text { yellowish gray [2dc] light } \\
\text { grayish yellow brown [3ge] } \\
\text { none }\end{array}$ \\
\hline $\begin{array}{l}\text { Yeast extract - } \\
\text { malt extract agar } \\
\text { (ISP-2 medium) }\end{array}$ & $\begin{array}{l}\text { G: } \\
\text { AM: } \\
\text { SM: } \\
\text { SP: }\end{array}$ & $\begin{array}{l}\text { abundant } \\
\text { grayish yellow pink [5dc] } \\
\text { or at a somewhat later } \\
\text { stage, light gray [d] } \\
\text { moderately yellowish pink } \\
{[4 \mathrm{gc}] \sim \text { light brown [4ie] }} \\
\text { none }\end{array}$ & $\begin{array}{l}\text { Glucose - } \\
\text { asparagine } \\
\text { agar }\end{array}$ & $\begin{array}{l}\text { G: } \\
\text { AM: } \\
\text { SM: } \\
\text { SP: }\end{array}$ & $\begin{array}{l}\text { abundant } \\
\text { light gray [d] } \\
\text { pale yellow [2db] light } \\
\text { olive brown [2ge], later } \\
\text { turning to be yellow pink } \\
\text { [5dc] } \\
\text { none }\end{array}$ \\
\hline $\begin{array}{l}\text { Oatmeal agar } \\
\text { (ISP-3 medium) }\end{array}$ & $\begin{array}{l}\text { G: } \\
\text { AM: } \\
\text { SM: } \\
\text { SP: }\end{array}$ & $\begin{array}{l}\text { good } \\
\text { light brownish gray [3fe] } \\
\text { light grayish reddish brown } \\
\text { [5fe] } \\
\text { grayish yellow [3ec] light } \\
\text { orange yellow [3ea] } \\
\text { brown (slightly) }\end{array}$ & $\begin{array}{l}\text { Glycerol - } \\
\text { asparagine } \\
\text { agar }\end{array}$ & $\begin{array}{l}\text { G: } \\
\text { AM: } \\
\text { SM: } \\
\text { SP: }\end{array}$ & $\begin{array}{l}\text { moderate } \\
\text { light gray [d] light } \\
\text { grayish reddish brown }[5 \mathrm{fe}] \\
\text { yellowish pink }[4 \mathrm{gc}] \sim \\
\text { light brown }[4 \mathrm{ie}] \\
\text { none }\end{array}$ \\
\hline $\begin{array}{l}\text { Calcium malate } \\
\text { agar }\end{array}$ & $\begin{array}{l}\text { G: } \\
\text { AM: }\end{array}$ & $\begin{array}{l}\text { moderate } \\
\text { light gray }[\mathrm{d}] \sim \text { light } \\
\text { grayish reddish brown } \\
{[5 \mathrm{fe}]} \\
\text { colorless } \sim \text { pale yellow } \\
{[2 \mathrm{db}] \text { or yellowish gray }} \\
{[2 \mathrm{dc}]} \\
\text { none }\end{array}$ & $\begin{array}{l}\text { Starch - } \\
\text { inorganic salt } \\
\text { agar } \\
\text { (ISP-4 medium) }\end{array}$ & $\begin{array}{l}\text { G: } \\
\text { AM: } \\
\text { SM: } \\
\text { SP: }\end{array}$ & $\begin{array}{l}\text { good } \\
\text { light gray }[\mathrm{d}] \\
\text { pale yellow }[2 \mathrm{db}] \sim \text { gray } \\
{[2 \mathrm{fe}]} \\
\text { none }\end{array}$ \\
\hline $\begin{array}{l}\text { Glucose - peptone - } \\
\text { gelatin } \\
\text { (cultivated at } 20^{\circ} \mathrm{C} \text { ) }\end{array}$ & $\begin{array}{l}\text { G: } \\
\text { AM: } \\
\text { SM: } \\
\text { SP: }\end{array}$ & $\begin{array}{l}\text { good } \\
\text { white }[\mathrm{b}] \sim \text { grayish yellow } \\
\text { pink }[5 \mathrm{cb}] \\
\text { pale yellow }[2 \mathrm{bd}] \sim \text { brown } \\
\text { brown }\end{array}$ & $\begin{array}{l}\text { Tyrosine agar } \\
\text { (ISP-7 medium) }\end{array}$ & $\begin{array}{l}\text { G: } \\
\text { AM: } \\
\text { SM: } \\
\text { SP: }\end{array}$ & $\begin{array}{l}\text { moderate } \\
\text { light gray }[\mathrm{d}] \sim \text { light } \\
\text { brownish gray [3fe] } \\
\text { grayish yellow [3ec] } \sim \\
\text { light brown [4ie] } \\
\text { none }\end{array}$ \\
\hline
\end{tabular}

* G: growth, AM: aerial mycelium, SM: substrate mycelium, SP: soluble pigment. [ ] : color code of the Color Harmony Manual ${ }^{19)}$.

Table 2. Physiological properties of strain OA6129.

\begin{tabular}{|c|c|}
\hline Growth temperature & $\begin{array}{l}\text { growth occurs at } 10 \sim 40^{\circ} \mathrm{C} \\
\text { better growth at } 20 \sim 30^{\circ} \mathrm{C}\end{array}$ \\
\hline Liquefaction of gelatin & positive \\
\hline Hydrolysis of starch & positve \\
\hline $\begin{array}{l}\text { Coagulation of skimmed } \\
\text { milk }\end{array}$ & $\begin{array}{l}\text { peptonization without } \\
\text { coagulation }\end{array}$ \\
\hline $\begin{array}{l}\text { Formation of melanoid } \\
\text { pigment }\end{array}$ & $\begin{array}{l}\text { no melanoid pigment is } \\
\text { formed in peptone-yeast } \\
\text { extract-iron agar (ISP-6 } \\
\text { medium) and Tryptone- } \\
\text { yeast extract broth (ISP-11 } \\
\text { medium). } \\
\text { In tyrosine agar, slightly } \\
\text { brown color is observed } \\
\text { with a trace amount of } \\
\text { melanin. }\end{array}$ \\
\hline
\end{tabular}

Table 3. Utilization of carbon sources by strain OA-6129.

\begin{tabular}{l|c}
\hline Carbon source & Growth \\
\hline L-Arabinose & + \\
D-Xylose & + \\
D-Glucose & + \\
D-Fructose & + \\
Sucrose & \pm \\
Inositol & - \\
L-Rhamnose & + \\
Raffinose & - \\
D-Mannitol & + \\
\hline
\end{tabular}

Symbols: +; positive, \pm ; doubtful, -; negative 
Fermentation

One hundred milliliters of the 48 hour-old culture of Streptomyces sp. OA-6129 in a 500-ml Erlenmeyer flask was inoculated into a 30-liter jar fermentor containing 15 liters of seed medium SE-4 (Table 4) and was cultivated at $28^{\circ} \mathrm{C}$ for 24 hours, using an agitation rate of $200 \mathrm{rpm}$ and an aeration rate of 0.5 volume/volume/minute. One liter of the seed culture was transferred into a 200 -liter stainless steel fermentor containing 100 liters of medium GM-1 (Table 4). The fermentor was operated at $28^{\circ} \mathrm{C}$ under forced aeration (agitation $200 \mathrm{rpm}$; aeration 0.5 volume/volume/minute).

The production of the OA-6129 group of antibiotics was traced by the disk-agar diffusion assay with Comamonas terrigena B-996 using PS-5 sodium salt as a tentative bioassay standard. Growth of the microorganism was measured in the packed volume of sediment by centrifuging $3 \mathrm{ml}$ of a broth sample at 1,500 rpm for 15 minutes. The concentration of glycerol was determined by the method of IwAI et al. ${ }^{21)}$. A typical time course of fermentation of Streptomyces sp. OA-6129 is illustrated in Fig. 2.

Thin-layer Chromatographic Analysis of the Fermentation Broth

By the newly-developed thin-layer chromatographic method, the fermentation broths of Strepto-

Table 4. Seed medium and fermentation medium.

\begin{tabular}{|c|c|c|c|}
\hline \multicolumn{2}{|l|}{ Seed medium (SE-4) } & \multicolumn{2}{|c|}{ Production medium (GM-1) } \\
\hline Beef extract (Difco) & $0.3 \%$ & Glycerol & $8.0 \%$ \\
\hline Bacto - Tryptone (Difco) & $0.3 \%$ & Fish meal & $1.0 \%$ \\
\hline Defatted soybean meal & $0.5 \%$ & Defatted soybean meal & $3.0 \%$ \\
\hline Glucose & $0.1 \%$ & $\mathrm{CaCO}_{3}$ & $0.3 \%$ \\
\hline Soluble starch & $2.4 \%$ & $\mathrm{~K}_{2} \mathrm{HPO}_{4}$ & $0.2 \%$ \\
\hline Yeast extract & $0.4 \%$ & $\mathrm{MgSO}_{4}$ & $0.2 \%$ \\
\hline $\mathrm{CaCO}_{3}$ & $0.4 \%$ & $\mathrm{pH}$ (adjusted with $\mathrm{NaOH}$ & \\
\hline \multirow[t]{2}{*}{ pH (before sterilization) } & 7.5 & before sterilization) & 7.5 \\
\hline & & \multicolumn{2}{|c|}{$\begin{array}{l}\text { Vitamin } \mathrm{B}_{12} \text { in } 0.01 \mathrm{M} \text { phosphate buffer, } \\
\text { pH } 5.5 \text {, was separately autoclaved for } \\
5 \text { minutes at a pressure of } 1 \mathrm{~kg} / \mathrm{cm}^{2} \cdot \mathrm{G} \\
\text { and added in an amount of } 0.0005 \% \\
(\mathrm{w} / \mathrm{v}) .\end{array}$} \\
\hline
\end{tabular}

Fig. 2. A typical time course of the fermentation by strain OA-6129 in a 200-liter fermentor.

Medium: GM-1. Temperature: $28^{\circ} \mathrm{C}$. Agitation and aeration: $200 \mathrm{rpm}, 0.5 \mathrm{vol} . / \mathrm{vol} . /$ minute.

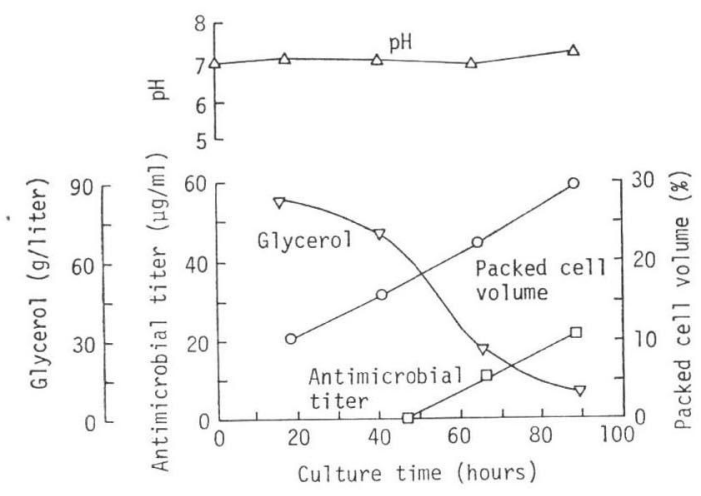

Fig. 3. Thin-layer chromatograms of the fermentation broths of Streptomyces sp. OA-6129 and Streptomyces fulvoviridis A933.

Plate: Silica gel $60 \mathrm{~F}_{254}$ (Merck)

Solvent system: $\mathrm{CH}_{3} \mathrm{CN}-0.75 \% \mathrm{CH}_{3} \mathrm{COOH}$,

Detection: $\quad$ Ehrlich reagent

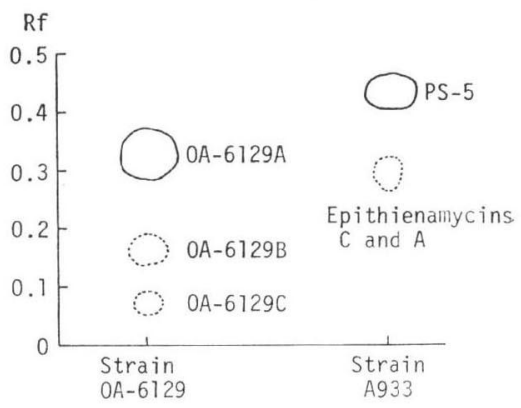


myces sp. OA-6129 and Streptomyces fulvoviridis A933') were compared (Fig. 3).

It is apparent from Fig. 3 that, in this run of fermentation, OA-6129A was a major component together with small amounts of OA-6129B and OA-6129C. The thin-layer chromatographic analysis which will be reported elsewhere ${ }^{11)}$ was found to be very convenient for component analysis of fermentation broths, as it was rapid, semi-quantitative, less expensive and easy to run in comparison with the conventional methods such as paper chromatography, high voltage paper electrophoresis and high performance liquid chromatography.

\section{Isolation and Purification}

Procedures for isolation and purification of OA-6129A, OA-6129B, OA-6129B $\mathrm{B}_{2}$ and OA-6129C are schematically presented in Figs. 4-a, 4-b and 4-c.

The fermentation broth (100 liters) of Streptomyces sp. OA-6129 was mixed with 5\% of Topco Perlite No. 34 (a filter aid produced by Toko Perlite Co., Ltd., Japan) and then filtered with a filter press. The clear filtrate (90 liters) was adsorbed on a chromatographic column (15 $\times 100 \mathrm{~cm}$ ) of Diaion HP 20 (Mitsubishi Chemical Industries Ltd., Japan) and the column was eluted with $30 \%$ aqueous acetone. Antimicrobially active fractions were collected; combined

Fig. 4-b. Purification process for compounds OA$6129 \mathrm{~A}, \mathrm{~B}_{1}$ and $\mathrm{B}_{2}$.

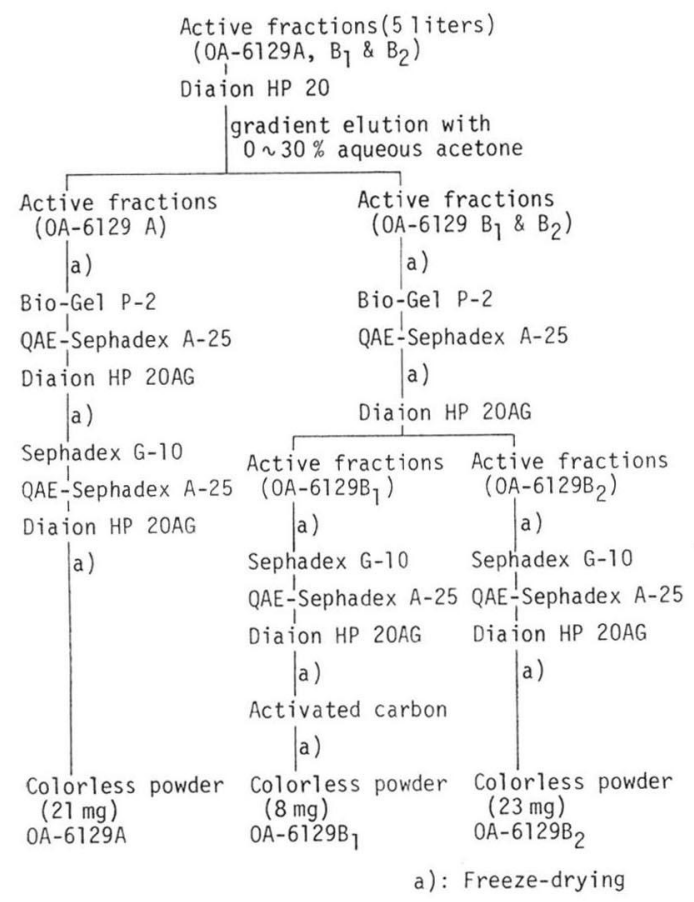

Fig. 4-a. Recovery process for the OA-6129 group of antibiotics from the fermentation broth.

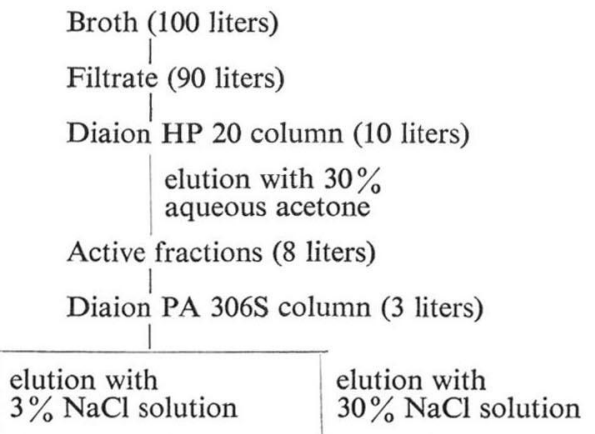

Active fractions (8 liters) Active fractions (7 liters) (OA-6129A, $\mathrm{B}_{1}$ and $\left.\mathrm{B}_{2}\right) \quad$ (OA-6129C)

Fig. 4-c. Purification process for compound OA$6129 \mathrm{C}$.

Active fractions (7 liters)
(OA-6129C)
Diaion HP 20
\[ \begin{array}{l}\text { extraction with methylene } \\ \text { chloride containing } 3 \% \\ \text { alkyldimethylbenzyl- } \\ \text { ammonium chloride } \\ \text { back-extraction with } \\ 8 \% \text { sodium iodide }\end{array} \]

Bio-Gel P-2

Diaion HP 20

QAE-Sephadex A-25

Diaion HP 20AG

freeze-drying

Sephadex G-10

QAE-Sephadex A-25

Diaion HP 20AG

freeze-drying

Colorless powder $(13 \mathrm{mg})$

(OA-6129C) 
and charged on a Diaion PA $306 \mathrm{~S}$ column $(8 \times 60 \mathrm{~cm}$; Mitsubishi Chemical Industries Ltd., Japan). With $3.0 \%$ sodium chloride as eluant, fractions containing OA-6129A, OA-6129 $\mathrm{B}_{1}$ and OA-6129. were first collected from the column. Subsequently the concentration of sodium chloride in the eluant was increased to $30 \%$ for elution of OA-6129C (Fig. 4-a).

The solution containning OA-6129A, OA-6129 $\mathrm{B}_{1}$ and $\mathrm{OA}-6129 \mathrm{~B}_{2}$ was subjected to successive column chromatographies using Diaion HP 20, Bio-Gel P-2 (Bio-Rad Laboratories, U.S.A.), QAESephadex A-25 (Pharmacia Fine Chemicals AB, Sweden) and Diaion HP 20AG (Mitsubishi Chemical Industries Ltd., Japan), as is illustrated in Fig. 4-b. The final yields of OA-6129A, OA-6129B B $_{1}$ and OA$6129 \mathrm{~B}_{2}$ were $21 \mathrm{mg}, 8 \mathrm{mg}$ and $23 \mathrm{mg}$ respectively.

OA-6129C was assumed to have a sulfuryl function on the basis of its high voltage electrophretic data. The extraction process with a quarternary ammonium salt, which was described for isolation

Fig. 5-a. IR spectrum of compound OA-6129A in $\mathrm{KBr}$.

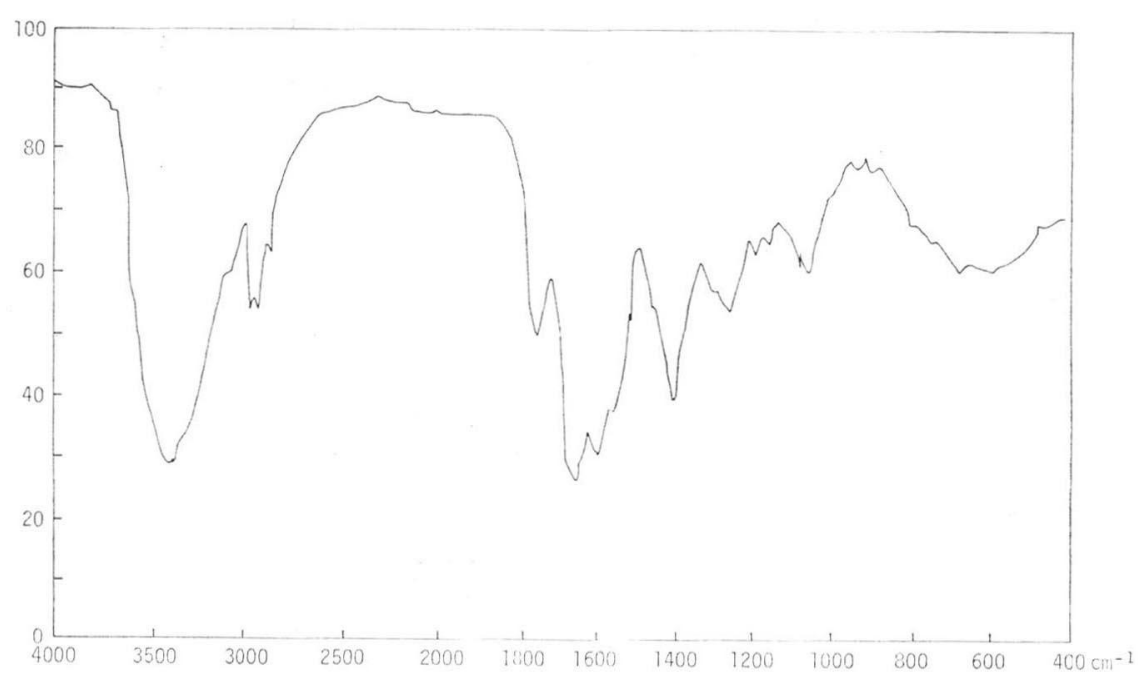

Fig. 5-b. IR spectrum of compound OA-6129 $\mathrm{B}_{1}$ in $\mathrm{KBr}$.

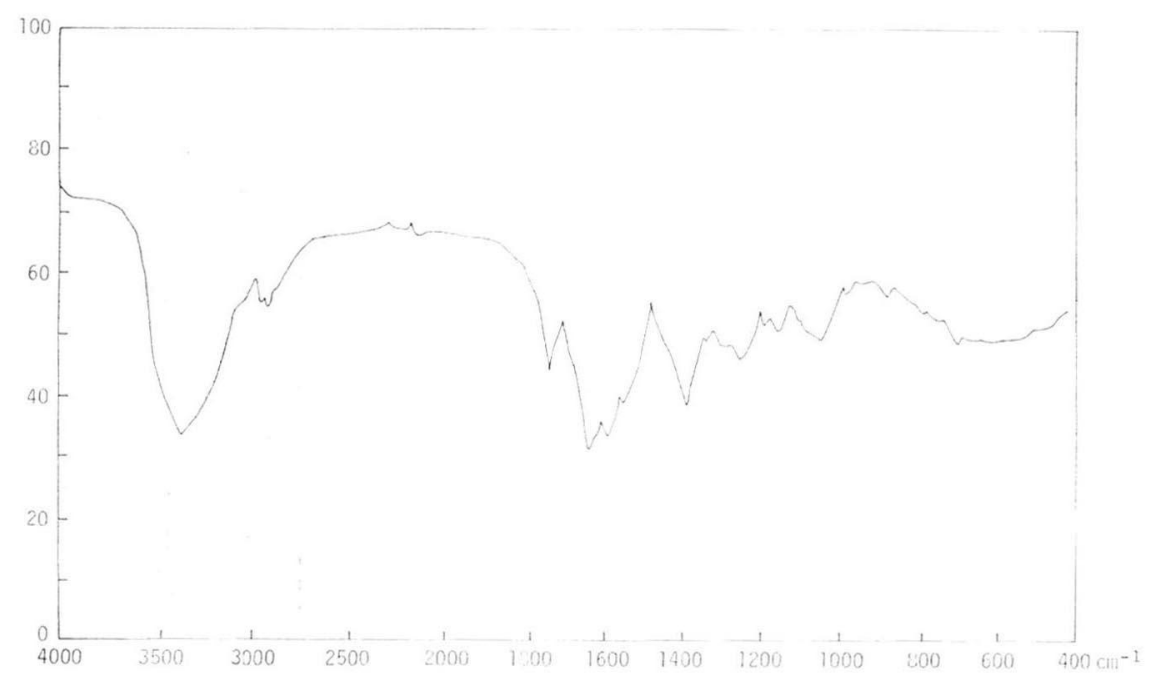


and purification of the olivanates ${ }^{5)}$, was effectively employed for preparation of OA-6129C. After desalting with Diaion HP 20, the OA-6129C solution from Fig. 4-a was extracted with methylene chloride containing 3.0\% alkyldimethylbenzylammonium chloride (Tokyo Chemical Industry Co., Ltd., Japan). The organic layer was separated and back-extracted with $8.0 \%$ sodium iodide. According to the basically same processes as for OA-6129A, OA-6129B $\mathrm{B}_{1}$ and $\mathrm{OA}-6129 \mathrm{~B}_{2}$, the aqueous solution of OA$6129 \mathrm{C}$ was purified to give $13 \mathrm{mg}$ of colorless powder of OA-6129C (Fig. 4-c).

\section{Physicochemical Properties}

The four carbapenem compounds were isolated as the substantially pure sodium salts. They are freely soluble in water, methanol and ethanol, but practically insoluble in other common organic solvents. Their IR absorption spectra are reproduced in Figs. 5-a, 5-b, 5-c and 5-d.

Fig. 5-c. IR spectrum of compound of $\mathrm{OA}-6129 \mathrm{~B}_{2}$ in $\mathrm{KBr}$.

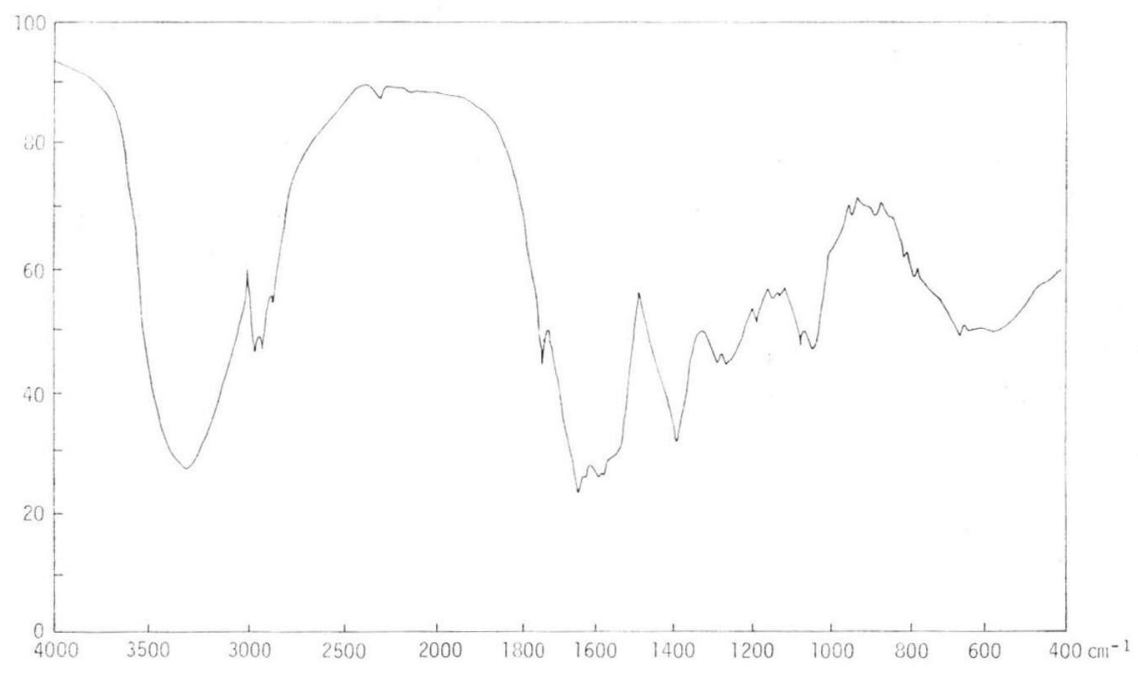

Fig. 5-d, IR spectrum of compound OA-6129C in $\mathrm{KBr}$.

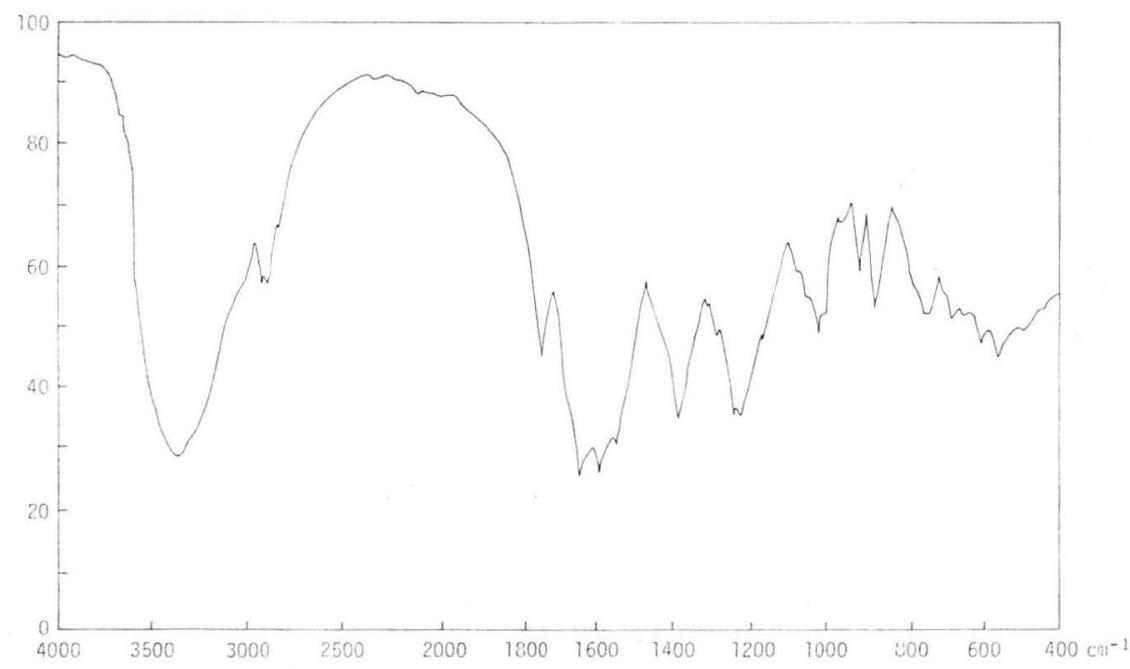


Table 5. Physicochemical properties of the OA-6129 group of antibiotics.

\begin{tabular}{|c|c|c|c|c|}
\hline & OA-6129A & OA-6129B & $\mathrm{OA}-6129 \mathrm{~B}_{2}$ & OA-6129C \\
\hline Appearance & Colorless & Colorless & Colorless & Colorless \\
\hline $\mathrm{IR} \nu_{\max }^{\mathrm{KBr}} \mathrm{cm}^{-1}$ & $1760,1660,1600$ & $1750,1650,1590$ & $1760,1660,1600$ & $\begin{array}{l}1750, \\
1660 \sim 1595, \\
1250 \sim 1220\end{array}$ \\
\hline $\mathrm{UV} \lambda_{\max }^{\mathrm{H}_{2} \mathrm{O}} \mathrm{nm}(\varepsilon)$ & $300(5,600)$ & $300(6,400)$ & $300(5,400)$ & $300.5(7,600)$ \\
\hline $\begin{array}{l}\text { Optical } \\
\text { rotation }[\alpha]_{\mathrm{D}}^{24}\end{array}$ & $\begin{array}{l}11.6^{\circ} \text { (c } 1.0, \\
0.01 \text { M PBS*, } \\
\text { pH } 8.4)\end{array}$ & $\begin{array}{l}24.2^{\circ} \\
\left.\mathrm{H}_{2} \mathrm{O}\right)\end{array}\left(\begin{array}{ll}c & 0.5\end{array}\right.$ & $\begin{array}{l}14.7^{\circ}(c 1.0 \\
0.01 \text { M PBS* } \\
\text { pH 8.4) }\end{array}$ & $\begin{array}{l}17.4^{\circ}(c 0.55 \\
0.01 \text { м PBS* } \\
\text { pH 8.2) }\end{array}$ \\
\hline HVPE $\mathrm{Rm}^{* *}$ & 0.67 & 0.67 & 0.67 & 1.69 \\
\hline $\mathrm{PC} \quad \mathrm{Rf} * * *$ & 0.29 & 0.17 & 0.17 & 0.09 \\
\hline
\end{tabular}

* $\quad$ PBS $=$ phosphate buffer.

** HVPE = high voltage paper electrophoresis; $1,500 \mathrm{~V} / 35 \mathrm{~cm}$ in Veronal buffer, pH 8.6 (I 0.027 ); $\mathrm{Rm}=$ relative to PS-5 sodium salt.

*** $\quad \mathrm{PC}=$ paper chromatography (descending); acetonitrile $-0.1 \mathrm{M}$ tris- $\mathrm{HCl}$ (pH 7.5) - 0.1 M EDTA (pH 7.5), 120: 30: 1 .

Table 5 summarizes the physicochemical data, relative HVPE mobilities and $\mathrm{Rf}$ values of the OA-6129 group of carbapenem compounds.

The in vitro evaluation of the antimicrobial activities of OA-6129A, OA-6129B , OA-6129B $_{2}$ and $\mathrm{OA}-6129 \mathrm{C}$ will be reported in the subsequent paper $^{23)}$.

\section{Comparative $\mathrm{pH}$ Stabilities of OA-6129A and PS-5}

Chemical stabilities of OA-6129A and PS-5 in aqueous solution were compared at the indicated $\mathrm{pH}$ 's by UV spectrometry.

Fig. 6 shows that OA-6129A is significantly more stable than PS-5 over the pH range tested, although both compounds are practically stable only in a narrow range of $\mathrm{pH}$ close to neutrality. The other members of the OA-6129 group seem to have the substantially same $\mathrm{pH}$ stabilities as OA-6129A, indicating that the 3-pantetheinyl side chain serves to stabilize the carbapenem nucleus.
Fig. 6. Comparative pH stabilities of OA-6129A and PS-5.

The amount of unchanged carbapenem in $0.05 \mathrm{M}$ phosphate buffer was followed at $28^{\circ} \mathrm{C}$ by spectrometry.

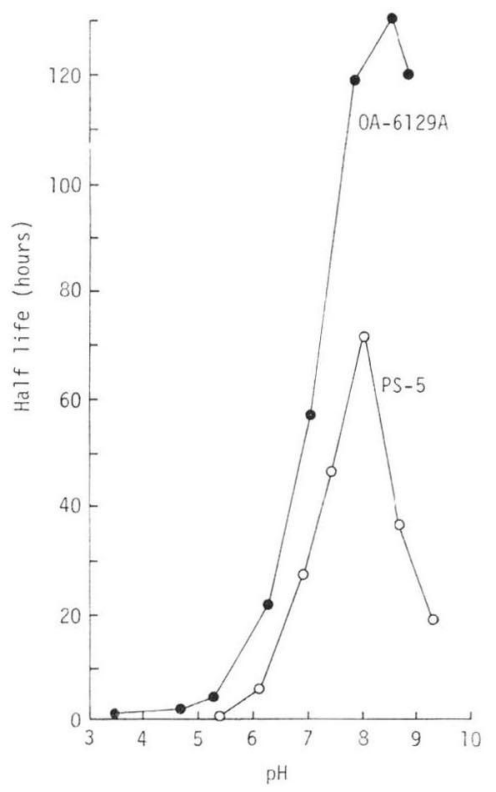

\section{References}

1) Okamura, K.; A. Koki, M. Sakamoto, K. Kubo, Y. Mutoh, Y. Fukagawa, K. Kouno, Y. Shimauchi, T. IshikURA \& J. LeIN: Microorganisms producing a new $\beta$-lactam antibiotic. J. Ferment. Technol. 57: $265 \sim 272,1979$

2) Shibamoto, N.; A. Koki, M. Nishino, K. Nakamura, K. Kiyoshima, K. Okamura, M. Okabe, R. Okamoto, Y. Fukagawa, Y. Shimauchi, T. Ishikura \& J. LeIn: PS-6 and PS-7, new $\beta$-lactam antibiotics. Isolation, physicochemical properties and structures. J. Antibiotics 33: 1128 1137, 1980 
3) Shibamoto, N.; M. Nishino, K. Okamura, Y. Fukagawa \& T. Ishikura: PS-8, a minor carbapenem antibiotic. J. Antibiotics 35: 763 765, 1982

4) Yoshioka, T.; I. Kojima, K. Isshiki, A. Watanabe, Y. Shimauchi, M. Okabe, Y. Fukagawa \& T. IsHIKURA: Structural elucidation of OA-6129A, $B_{1}, B_{2}$ and C, new carbapenem antibiotics. Tetrahed. Lett. (under preparation)

5) Butterworth, D.; M. Cole, G. Hanscomb \& G. N. Rolinson: Olivanic acids, a family of $\beta$-lactam antibiotics with $\beta$-lactamase inhibitory properties produced by Streptomyces species. I. Detection, properties and fermentation studies. J. Antibiotics 32: 287 294, 1979

6) Kahan, J. S.; F. M. Kahan, R. Geogelman, S. A. Currie, M. Jackson, E. O. Stapley, T. W. Miller, A. K. Miller, D. Hendlin, S. Mochales, S. Hernandez, H. B. Woodruff \& J. Birnbaum: Thienamycin, a new $\beta$-lactam antibiotic. I. Discovery, taxonomy, isolation and physical properties. J. Antibiotics 32: $1 \sim 12,1979$

7) Stapley, E. O.; P. J. Cassidy, J. Tunac, R. L. Monaghan, M. Jackson, S. Hernandez, S. B. Zimmerman, J. M. Mata, S. A. Currie, D. Daoust \& D. Hendlin: Epithienamycins - Novel $\beta$-lactams related to thienamycin. I. Production and antibacterial activity. J. Antibiotics 34: 628 636, 1981

8) Nakayama, M.; A. Ifasaki, S. Kimura, T. Mizoguchi, S. Tanabe, A. Murakami, I. Watanabe, M. OKuchi, H. ITOH, Y. SAINo, F. KobaYAShI \& T. Mori: Carpetimycins A and B, new $\beta$-lactam antibiotics. J. Antibiotics 33: 1388 1390, 1980

9) Imada, A.; Y. Nozaki, K. Kintaka, K. Okonogi, K. Kitano \& S. Harada: C-19393 $\mathrm{S}_{2}$ and $\mathrm{H}_{2}$, new carbapenem antibiotics. I. Taxonomy of the producing strain, fermentation and antibacterial properties. J. Antibiotics 33: 1417 1424, 1980

10) Kawamura, Y.; Y. Yasuda, M. Mayama \& K. TanaKa: Asparenomycins A, B and C, new carbapenem antibiotics. I. Taxonomic studies on the producing microorganisms. J. Antibiotics 35: 10 14, 1982

11) OKabe, M.; K. Kiyoshima, I. Kojima, R. OKamoto, Y. Fukagawa \& T. Ishikura: Analysis of carbapenem antibiotics in fermentation broth by thin layer chromatography. J. Chromatogr. (under preparation)

12) Shirling, E. B. \& D. Gottlieb: Methods for characterization of Streptomyces species. Intern. J. Syst. Bacteriol. 16: $313 \sim 340,1966$

13) Shirling, E. B. \& D. Gottlieb: Cooperative description of type culture of Streptomyces. II. Species description from first study. Intern. J. Syst. Bacteriol. 18: 69 198, 1968

14) Shirling, E. B. \& D. Gottlieb: Cooperative description of type culture of Streptomyces. III. Additional species descriptions from first and second studies. Intern. J. Syst. Bacteriol. 18: 278 392, 1968

15) Shirling, E. B. \& D. Gottlieb: Cooperative description of type culture of Streptomyces. IV. Species description from second, third and fourth studies. Intern. J. Syst. Bacteriol. 19: $391 \sim 512$, 1969

16) Shirling, E. B. \& D. Gottlieb: Cooperative description of type culture of Streptomyces. V. Additional descriptions. Intern. J. Syst. Bacteriol. 22: 265 394, 1972

17) Pridham, T. G. \& H. D. Tresner: Bergey's Manual of Determinative Bacteriology, 8th Edition. pp. $747 \sim 829$, The Williams and Wilkins Co., Baltimore, 1974

18) Waksman, S. A.: The Actinomycetes. Vol. 2, The Williams and Wilkins Co., Baltimore, 1961

19) Jacobson, E.; E. W. Granville \& C. E. Foss: Color Harmony Manual, 3rd Ed., Container Corporation of America, Chicago, 1948

20) Tresner, H. D. \& E. J. Backus: System of color wheels for streptomycete taxonomy. J. Appl. Microbiol. 11: 335 338, 1963

21) IWAI, Y.; S. ŌMURA \& T. Hata: The determination of glycerol in the broth of an antibiotic producing culture of Streptomyces sp. J. Ferment. Technol. 49: 842 846, 1971

22) Okabe, M.; K. Kiyoshima, I. Kojima, S. Azuma, R. Окамото, Y. Fukagawa \& T. Ishikura: Development and application of a thin-layer chromatographic method for analysis of carbapenem antibiotics. J. Ferment. Technol. (under preparation)

23) Sakamoto, M.; I. Kojima, M. Okabe, Y. Fukagawa \& T. Ishikura: Studies on the OA-6129 group of antibiotics, new carbapenem compounds. II. In vitro evaluation. J. Antibiotics 35: 1264 1270, 1982 